\title{
Euphoria from drinking alcoholic beverages may be due to reversible constriction of cerebral blood vessels: potential roles of unrecognized ionized hypomagnesemia, and release of ceramides and platelet-activating factor
}

\author{
Burton M. Altura ${ }^{1-5 *}$, Aimin Zhang ${ }^{1}$, Nilank C. Shah ${ }^{1,2}$, Gatha J. Shah ${ }^{1}$, Asefa Gebrewold ${ }^{1}$ and Bella T. Altura ${ }^{1,3-5}$ \\ ${ }^{1}$ Department of Physiology and Pharmacology, SUNY Downstate Medical Center 450 Clarkson Avenue Brooklyn, NY 11203, USA \\ ${ }^{2}$ Department of Medicine, SUNY Downstate Medical Center 450 Clarkson Avenue Brooklyn, NY 11203, USA \\ ${ }^{3}$ Center for Cardiovascular and Muscle Research, SUNY Downstate Medical Center 450 Clarkson Avenue Brooklyn, NY 11203, USA \\ ${ }^{4}$ The School of Graduate Studies in Molecular and Cellular Science, The State University of New York Downstate Medical Center, Brooklyn, NY, USA; \\ ${ }^{5}$ Bio-Defense Systems, Inc, Rockville Centre, NY, USA
}

Euphoria is an affective state and a form of pleasure that goes back to biblical times. It makes a person experience intense forms of well-being, happiness, and often ecstasy. It has often been suggested that euphoria induced by alcohol and other drugs/compounds (e.g., psychoactive drugs, designer drugs, stimulants, nicotine, gamma-hydroxybutyric acid, ketamine, etc.) occurs via a stimulation of all hedonic hotspots within the brain's reward system [1]. Interestingly, asphyxiation initially produces an intense feeling of euphoria, often leading people to intentionally induce asphyxiation and erotic sensations (i.e., brief episodes of hypoxia such as choking).

More than 35 years ago, three of us, using a TV-imageintensification recording system, at magnifications up to 3,200 times (pioneered by our lab) [2] and using in-vivo examination of the living brain microcirculation in different anesthetized rodents (i.e., rats, mice, guinea-pigs) reported that very small amounts of alcohol (equivalent to one-two drinks) reversibly constricted arterioles (20-40 $\mu \mathrm{m}$ in diameter) and muscular venules (40-75 um in diameter) [3]. These initial findings suggested to us that the amount of alcohol in only two cocktail drinks may be enough to curtail blood flow in the brain to the point that some key neurons, glial cells, and astrocytes do not get enough oxygen to function properly. We suggested, like that seen in pilots at high altitude (> 15,000 feet) in non-pressurized cabins, in World War II, who experienced a euphoric sense of well-being, drinking of alcohol and the taking of diverse psychoactive/designer drugs can reversibly induce vasoconstriction of the cerebral microscopic blood vessels, thus producing oxygen-lack and temporary light-headedness and euphoria. The neurons, glial cells, and astrocytes in select areas of the brain would thus be starved for oxygen like unprotected pilots at high-altitude. Until the advent of pressurized cabins, many pilots in World War II became very euphoric, blacked out, lost control of their aircraft and perished.

Using isolated arteries from brains of anesthetized, sacrificed rats, guinea-pigs, dogs, and subhuman primates, bathed in physiological salt solutions, our laboratories found that various alcohols (i.e., ethanol, methanol, and butanol) caused concentration-dependent contractions, similar to the in-vivo studies on the living brains of rodents [3-15]. The greater the dose of alcohol, the greater the vasoconstrictor-contractile effects and the longer the contractions remain unabated [3-16]. Such effects clearly could be the cause of the sequelae of effects noted with increased consumption of cocktails, beers, and various liquors, i.e., the failure to be able to walk a straight line, the failure to drive a vehicle safely, unconsciousness, coma and in rare cases strokes and death [3,7-16]. Drinking of alcohol thus can be, and often is, lethal. In fact, drinking of alcohol is the most abused type of drug/behavior $[1,17,18]$. Other experiments from our group have shown that hallucinogenic drugs such as LSD, phencyclidine (PCP, "angel dust"), pysilocybin, mescaline, heroin, pyote, cocaine, excitatory amino acids and derivatves (i.e., designer drugs) also promote vasoconstriction of brain blood vessels [19-27]. The concentrations of PCP, mescaline, LSD and cocaine that produced near maximum and intense euphoria, often leading to death, were similar to the concentrations in the blood and brains of humans who had died from overdoses of PCP, LSD, and mescaline.

Using rats addicted to ethanol, we found that the in-situ cerebral micro vessels as well as cerebral and peripheral arteries (removed from the addicted animals) gradually, with the passage of time (and increased blood alcohol levels), became tolerant to the alcohol $[8,10,14$, unpublished findings]. In other words, it takes higher and higher concentrations of alcohol to induce microvascular contractions, which would thus produce a need for increased blood alcohol levels in order to induce euphoric states, exactly as occurs in humans with increased drinking. Breathing is controlled by the brain. Cutting off the blood supply to the neurons, etc., that regulate breathing may produce euphoria at very low concentrations of alcohol and hallucinations at higher blood levels of alcohol.

What, however, is the exact mechanism(s) which induce euphoria and hallucinations via a reduced cerebral vascular blood and oxygen supply? Until now, speculation resided in a release of endorphins,

Correspondence to: Burton M. Altura, Department of Physiology and Pharmacology, SUNY Downstate Medical Center 450 Clarkson Avenue Brooklyn, NY 11203, USA, Tel: (718) 270-2194; E-mail: baltura@downstate.edu

Received: October 25, 2016; Accepted: November 08, 2016; Published: November 14, 2016 
Altura BM (2016) Euphoria from drinking alcoholic beverages may be due to reversible constriction of cerebral blood vessels: potential roles of unrecognized ionized hypomagnesemia, and release of ceramides and platelet-activating factor

gamma-hydroxybutryic acid-like substances, and a variety of putative neurotransmitters $[14,15,17,18]$. However, none of these substances and multiple transmitters (e.g., norepinephrine, dopamine, serotonin, histamine, prostanoids, neuropeptides, glutamic acid, etc.) that we [1317, 28-31; unpublished studies on microvasculatures of rodent brains] and others have tested [32] produce ischemic actions in the brain microvasculature at blood levels found to be released with imbibing of alcohol.

We now believe that a rapid, reversible release of free magnesium ions $\left(\left[\mathrm{Mg}^{2+}\right]\right)$ coupled to the release of ceramides and platelet-activating factor(PAF) may account for most of the alcohol-induced euphoria. Below, we discuss why this hypothesis looks tenable to us.

Many drugs including alcohol are now known to induce reversible $\mathrm{Mg}^{2+}$ deficiency in organs, tissues, and cells in both animals and humans. Flink and his co-workers in 1954 were the first to demonstrate severe hypomagnesemia in alcoholic patients [33]. Over the succeeding years these findings have been confirmed and extended by others [34]. In fact, infusions of magnesium sulfate have been standard treatment of delirium tremens for a good number of years. Approximately 25 years ago, our group, for the first time, employing ${ }^{31} \mathrm{P}$-nuclear magnetic resonance ( $\left.{ }^{31} \mathrm{P}-\mathrm{NMR}\right)$ spectroscopy and optical spectroscopy on the living intact brains of animals as well as utilization of digital-imaging microscopy on a variety of isolated cerebral vascular smooth muscle (VSM) cells, and use of highly- specific $\mathrm{Mg}^{2+}$ electrodes, found that alcohol rapidly (i.e., within seconds) lowered intracellular free $\mathrm{Mg}^{2+}$ [12-15]. Using these techniques coupled with ${ }^{31} \mathrm{P}$ - NMR spectroscopy and measurements of lumen sizes (and microvascular blood flows) in the intact brains of rodents, as well as use of a variety of isolated cerebral arteries, we found profound concentration-dependent vasoconstriction of the blood vessels and increasing ischemia, as evidenced by rising cellular concentrations of inorganic phosphate coupled to acidic intracellular $\mathrm{pH}$, rises in deoxyhemoglobin, reduced mitochondrial levels of cytochrome oxidase and considerable loss of high-energy phosphate compounds [12-15].

$\mathrm{Mg}^{2+}$ is a co-factor for more than 500 enzymes, and is the second most abundant intracellular cation after potassium [35]. It is vital in numerous physiological, cellular and biochemical reactions including carbohydrate, lipid, protein, DNA and RNA metabolism, among other pathways $[35,36]$. Several epidemiologic studies in North America and Europe have shown that people consuming Western-type diets are low in $\mathrm{Mg}$ content (i.e., 30-65\% of the RDA for Mg) [37-40]; most such diets show that $60-80 \%$ of Americans are consuming $185-235 \mathrm{mg} /$ day of $\mathrm{Mg}[39,40]$. In 1900, in contrast, most Americans were consuming 450-550 mg/day of Mg [41]. Mg deficiency amongst the American and European populations could help to explain why, often, very low levels of alcohol can produce euphoric and hallucinatory events. This might also help to explain why many individuals do not experience euphoria or hallucinations after drinking more than two standard cocktail drinks containing alcohol, as their blood and tissue levels of $\mathrm{Mg}^{2+}$ are most likely elevated due to diets containing elevated levels of $\mathrm{Mg}$.

But, does low $\mathrm{Mg}^{2+}$-induced cerebral vasoconstriction and temporary ischemia in key areas of the brain account, in large measure for the euphoria, and if so, what is the molecular mechanism(s)? Approximately 40 years ago, two of us demonstrated using isolated cerebral, coronary, and peripheral arteries that a lowering of extracellular $\mathrm{Mg}^{2+}\left(\left[\mathrm{Mg}^{2+}\right]_{0}\right)$ levels resulted in a rapid rise in intracellular free calcium ions just prior to contractile events [42-44]. More recently, our group found that lowering of $\left[\mathrm{Mg}^{2+}\right]_{0}$ led to rapid activation of several isoforms of protein kinase C, P-I-3 kinases, mitogen-activated kinases, tyrosine-activated kinases [45-51], and at least five major enzymes in the sphingolipid biosynthetic pathway [52-61]. Prior to these findings, we $[41,52,62,63]$ and others $[64,65]$ reported that a variety of sphingolipid bi-products, namely ceramides, sphingosine, sphingosine-phosphates, etc., can induce contraction of VSM cells in the brain and elsewhere in the body. We have reported that inhibition of the activation of the major synthetic pathways for ceramides in cerebral VSM cells, using specific inhibitors for each enzyme, resulted in marked attenuation of the contractions of cerebral blood vessels upon the lowering of $\left[\mathrm{Mg}^{2+}\right]_{0}$ concomitant with reductions in the cellular rises of intracellular free $\mathrm{Ca}^{2+}$ [41,52,55-61, unpublished experiments]. Until very recently we believed that alcohol-induced cellular loss of $\left[\mathrm{Mg}^{2+}\right]$ coupled to cellular entry and release of $\mathrm{Ca}^{2+}$ with rapid synthesis of ceramides might explain a great deal of alcohol-induced cerebral vasoconstriction and brain ischemic events. However, we now believe at least one more cellular compound, namely PAF and PAF-like molecules, probably plays an important role in alcohol-induced brain ischemic events, euphoria, and hallucinations.

Why focus on PAF? PAF and PAF-like molecules are known to affect multiple physiologic aspects of neuronal and cardiac functions [66-68]. For example, PAF can produce coronary arterial vasoconstriction, lower arterial blood pressure, increase coronary vascular resistance, release several lipid-like molecules from the heart, reduce cardiac output, decrease cardiac contractility, alter atrial and papillary muscle chronotropicity and membrane action potentials, as well as alter potassium currents in isolated cardiomycytes [66-68]. All of these actions could lead one to believe that a rapid synthesis of PAF and PAF-like substances might play fundamental roles in alcoholinduced ischemia, euphoria, and hallucinations set into motion by a rapid lowering of $\left[\mathrm{Mg}^{2+}\right]$. As a first step in testing this hypothesis, we determined whether a rapid reduction in $\left[\mathrm{Mg}^{2+}\right]_{0}$ would result in the synthesis and release of PAF. Using isolated cerebral VSM cells in primary cell cultures, we recently reported that lowering $\left[\mathrm{Mg}^{2+}\right]_{0}$, as predicted, does indeed rapidly lead to the cellular synthesis and release of PAF and PAF-like substances [69]. We and others have clearly demonstrated that PAF and PAF-like substances induce vasoconstriction of cerebral arterioles and venules in the intact brains of rodents using TV-image -intensification microscopy [69]. Whether or not use of inhibitors of PAF and ceramide synthesis coupled to increased dietary intake of $\mathrm{Mg}$ will attenuate the euphoric and hallucinatory actions of ethanol imbibed in cocktails, beers, etc., remains to be tested, but in our opinion seems like a worthwhile undertaking.

\section{Acknowledgements}

Some of the original experimental and clinical studies mentioned in the above were supported, in part, by research grants from The N.I.H. (National Institute on Drug Abuse and The National Institute on Alcoholism and Alcohol Abuse to B.M.A. and B.T.A.). We also received some unrestricted grant support from several pharmaceutical companies including CIBA-GEIGY, Sandoz, and Bayer.

\section{References}

1. Kringelbach ML and Berridge KC (2013) The joyful mind. In: From Abuse to Recovery: Understanding Addiction. Macmillan, New York pp: 199-207.

2. Altura BM (1971) Do precapillary sphincters respond to vasoactive substances in an all-or-none manner. Proc Soc Exp Biol Med 138: 273-276. [Crossref]

3. Altura BM, Altura BT, Gebrewold A (1983) Alcohol-induced spasms of cerebral blood vessels: Relation to cerebrovascular accidents and sudden death. Science 220: 331-333.

4. Edgarian H, Altura BM (1976) Ethanol and contraction of venous smooth muscle 
Altura BM (2016) Euphoria from drinking alcoholic beverages may be due to reversible constriction of cerebral blood vessels: potential roles of unrecognized ionized hypomagnesemia, and release of ceramides and platelet-activating factor

Anesthesiology 44: 311-317. [Crossref]

5. Altura BM, Altura BT, Carella A, Chatterjee M, Halevy S, et al. (1982) Alcohol produces spasms of human umbilical blood vessels: Relationship to fetal alcohol syndrome. Eur J Pharmacol 77: 311-312.

6. Altura BM, Altura BT, Carella A (1983) Ethanol produces coronary vasospasm: evidence for a direct action of ethanol on vascular muscle. Br J Pharmacol 78: 260262. [Crossref]

7. Altura BM, Altura BT (1984) Alcohol, the cerebral circulation and strokes. Alcohol 1: 325-331. [Crossref]

8. Altura BM and Altura BT (1987) Peripheral and cerebrovascular actions of ethanol, acetaldehyde and acetate: relationship to divalent cations. Alcoholism: Clin Exp Res 10: 99-111.

9. Altura BM, Altura BT, Gebrewold A (1990) Comparative effects of ethanol, acetaldehyde and acetate on arterioles and venules in skeletal muscle: Direct in situ studies on the microcirculation and their possible relationship to alcoholic myopathy. Microcirc Endothelium Lymph 6: 107-126. [Crossref]

10. Altura BM and Altura BT (1991) Alcohol, stroke, and the cerebral circulation. Alcohol World Health \& Research 14: 322-332.

11. Zhang A, Altura BT, Altura BM (1993) Ethanol-induced contraction of cerebral arteries in diverse mammals and its mechanism of action. Eur J Pharmacol 248: 229-236. [Crossref]

12. Barbour RL, Gebrewold A, Altura BT (1993) Optical spectroscopy and cerebral vascular effects of ethanol in the intact brain: Effects on tissue deoxyhemoglobin, blood content and reduced cytochrome oxidase. Alcohol Clin Exp Res 17: 1319-1324. [Crossref]

13. Altura BM, Altura BT, Gupta RK (1991) Alcohol intoxication results in rapid loss in free magnesium in brain and disturbances in brain bioenergetics: relation to cerebrovasospasm, alcohol-induced strokes, and barbiturate-anesthesia induced deaths. Magnes Trace Elem 10: 122-135.

14. Altura BM and Altura BT (1996) Effect of alcohol on brain circulation. In: The Pharmacology of Alcohol and Alcohol Dependence. Begleiter H, Kissin B (Eds) Oxford Univ. Press, New York pp: 181-206.

15. Altura BT, Zhang A, Altura BM (1996) Differential actions of alcohol on peripheral, umbilical-placental and cerebral blood vessels: Implications for hypertension, fetal alcohol syndrome, stroke and alcohol tolerance. In: Alcohol and The Cardiovascular System. Zhakari S, Wassef M (Eds) NIAAA Research Monograph, Bethesda pp: 615645 .

16. Yang ZW, Wang J, Zheng T, Altura BT, Altura BM (2001) Ethanol-induced contractions in cerebral arteries: role of tyrosine and mitogen-activated protein kinases. Stroke 32: 249-256.

17. Lieber CS (1992) Medical and Nutritional Complications of Alcoholism. Mechanisms and Management. Plenum Medical, New York.

18. Ross R, Myers AK (2002) Alcohol and Heart Disease. Taylor and Francis, London.

19. Altura BT, Altura BM (1981) Phencyclidine, lysergic acid diethylamide, and mescaline: cerebral artery spasms and hallucinogenic drugs. Science 212: 1051-1053.

20. Altura BM, Altura BT (1983) Pharmacologic inhibition of cerebral vasospasm in ischemia, hallucinogen ingestion, and hypomagnesemia: barbiturates, calcium antagonists, and magnesium. Am J Emergency Med 1: 180-190.

21. Altura BM, Quirion R, Pert CB, Altura BM (1983) Phencyclidine analogs and sigmaopiate benzomorphans cause cerebral arterial spasm. Proc Nat Acad Sci USA 80: 865869. [Crossref]

22. Altura BT and Altura BM (1984) Effects of barbiturates, phencyclidine, ketamine and analogs on cerebral circulation and cerebrovascular muscle. Microcirc Endothelium Lymphatics 1: 169-184.

23. Altura BT, Altura BM, Quirion R (1984) Identification of benzomorphan-kappa opiate receptors in cerebral arteries which subserve relaxation. Br J Pharmacol 82: 459-466. [Crossref]

24. Huang QF, Gebrewold A, Altura BT, Altura BM (1990) Mg2+ protects against PCPinduced cerebrovasospasms and vascular damage in rat brain. Magnes Trace Elem 9: 44-46. [Crossref]

25. Huang QF, Gebrewold A, Altura BT, ltura BM (1990) Magnesium ions prevent phencyclidine-induced cerebrovasospasms and rupture of cerebral microvessels: Direct in-vivo microcirculatory studies on the brain. Neurosci Lett 113: 115-119.
26. Huang QF, Gebrewold A, Zhang A, Altura BT, Altura BM (1994) Role of excitatory amino acids in regulation of rat pial microvasculature. Am J Physiol 266: R158-163. [Crossref]

27. He GQ, Zhang A, Altura BT, Altura BM (1994) Cocaine-induced cerebrovasospasm and its possible mechanism of action. J Pharmacol Exp Ther 268: 1532-1539. [Crossref]

28. Altura BM, Lassoff S (1981) Perivascular action of the local anaesthetic, lidocaine, on pial terminal arterioles: direct observations on the microcirculation. Br J Pharmacol 73: 577-579. [Crossref]

29. Altura BM (1981) Pharmacology of the microcirculation. In: The Microcirculation. Effros EM, Ditzel J, Schmid-Schoinbein H (Eds) Academic Press, New York pp: 51105 .

30. Altura BM, Altura BT (1984) Actions of vasopressin, oxytocin, and synthetic analogs on vascular smooth muscle. Fed Proc 43: 80-86. [Crossref]

31. Altura BM (1984) Pharmacology of the microcirculation. In: Blood Vessels. Abramson DI, Dobrin PB (Eds)Academic Press, New York.

32. Edvinsson L, MacKenzie ET, McCulloch J (1993) Cerebral Blood Flow and Metabolism. Raven Press, New York.

33. Flink EB (1954) Magnesium deficiency syndrome in man. JAMA 160: 1406-1409.

34. Wacker WC (1980) Magnesium and Man. Harvard Press, Cambridge.

35. De Baaj JHE, Henderop JG, Bindels RJ (2015) Magnesium in man: implications for health and disease. Physiol Rev 95: 1-46.

36. Altura BM, Altura BT (1984) Magnesium, electrolyte transport, and coronary vascular tone. Drugs 28: 120-142.

37. Altura BM, Altura BT (1985) New perspectives on the role of magnesium in the pathophysiology of the cardiovascular system. I. Clinical aspects. Magnesium 4: 226244. [Crossref]

38. Ford ES1, Mokdad AH (2003) Dietary magnesium intake in a national sample of US adults. $J$ Nutr 133: 2879-2882. [Crossref]

39. Mosfegh A, Goldman J, Abuja J, Rhodes D, La Comb R (2006) What We Eat in America NHANES 2005-2006. Usual Nutrient Intakes from Food and Water Compared to 1997 Dietary Reference Intakes for Vitamin D, Calcium, Phosphorus, and Magnesium. U.S. Department of Agricultural Research.

40. Altura BM, Shah NC, Shah GJ, Altura BT (2016) Why is alcohol-induced atria arrhythmias and sudden cardiac death difficult to prevent and treat: potential roles of unrecognized ionized hypomagnesemia and release of ceramides and platelet-activating factor. Cardiovas pathol, an open access journal 1:3.

41. Altura BM, Altura BT (2007) Magnesium: forgotten mineral in cardiovascular biology In: New Perspectives in Magnesium Research. Springer, New York pp: 239-260.

42. Altura BM, Altura BT (1971) Influence of magnesium on drug-induced contractions and ion content in rabbit aorta. Am J Physiol 220: 938-944. [Crossref]

43. Altura BM, Altura BT (1981) General anesthetics and magnesium ions as calcium antagonists. In: New Perspectives on Calciun Antagonists. Am Physiol Soc pp: 131145

44. Altura BM, Altura BT (1974) Magnesium and contraction of arterial smooth muscle Microvasc Res 7: 145-155. [Crossref]

45. Yang ZW, Altura BT and Altura BM (1999) Low extracellular magnesium contraction of arterial muscle: role of protein kinase $\mathrm{C}$ and protein tyrosine phosphorylation. Eur J Pharmacol 378: 273-281.

46. Yang ZW, Gebrewold A, Nowakowski M, Altura BT, Altura BM (2000) Mg2+-induced endothelial dependent relaxation of blood vessels and blood pressure lowering: role of NO. Am J Physiol Regulatory Integr Comp Physiol 278: R628-R639.

47. Yang ZW, Wang J, Altura BT, Altura BM (2000) Extracellular magnesium deficiency induces contraction of arterial muscle: role of PI-3 kinases and MAPK signaling pathways. Pflug Arch European J Physiol 439: 240-247.

48. Yang ZW, Wang J, Zheng T, Altura BT, Altura BM (2000) Low extracellular $\mathrm{Mg} 2+$ induces contraction of cerebral arteries: roles of tyrosine and mitogen-activated protein kinases. Am J Physiol Heart Circ Physiol 279: H185-H194.

49. Yang ZW, Wang J, Zheng T, Altura BT and Altura BM (2001) Importance of PKC and PIK3Ks in ethanol-induced contraction of cerebral arterial smooth muscle. Am J Physiol Heart Circ Physiol 280: H2144-H2152.

50. Altura BM, Gebrewold A, Altura BT, Brautbar N (1996) Magnesium depletion impair carbohydrate and lipid metabolism and cardiac bioenergetics and raises calcium 
Altura BM (2016) Euphoria from drinking alcoholic beverages may be due to reversible constriction of cerebral blood vessels: potential roles of unrecognized ionized hypomagnesemia, and release of ceramides and platelet-activating factor

content in vivo: relationship to etiology of cardiac diseases. Biochem Mol Biol Int 40: $1183-1190$.

51. Altura BM, Kostellow AB, Zhang A, Li W, Morrill GA, et al. (2003) Expression of the nuclear factor-kB and proto-oncogenes c-fos and c-jun are induced by low extracellular $\mathrm{Mg} 2+$ in aortic and cerebral vascular smooth muscle cells: possible links to hypertension, atherogenesis, and stroke. Am J Hypertens 16: 347-359.

52. Altura BM, Altura BT (1995) Magnesium and cardiovascular biology: an importan link between cardiovascular risk factors and atherogenesis. Cell Mol Biol Res 41: 347359. [Crossref]

53. Morrill GA, Gupta RK, Kostellow AB, Ma GY, Zhang A, et al. (1997) Mg2+ modulates membrane lipids in vascular smooth muscle: a link to atherogenesis. FEBS Lett 408: 191-194. [Crossref]

54. Morrill GA, Gupta RK, Kostellow AB, Ma GY, Zhang A, et al. (1998) Mg2+ modulates membrane sphingolipid and lipid second messenger levels in vascular smooth muscle cells. FEBS Lett 440: 167-171. [Crossref]

55. Altura BM, Shah NC, Li Z, Jiang XC, Perez-Albela JL, et al (2010) Magnesium deficiency upregulates serine palmitoyl transferase(SPT 1 and SPT 2) in cardiovascular tissues: relationship to serum ionized $\mathrm{Mg} 2+$ and cytochrome C. Am J Physiol Heart Circ Physiol 299: H932-H938.

56. Altura BM, Shah NC, Li Z, Jiang X-C, Zhang A, Li W, et al. (2010) Short-term magnesium deficiency upregulates sphingomyelin synthase and $\mathrm{p} 53$ in cardiovascular tissues and cells: relevance to the de novo synthesis of ceramide. Am J Physiol Heart Circ Physiol 299: 2055-2055.

57. Shah NC, Liu JP, Iqbal J, Hussain M, Jiang X-C, et al. (2011) Mg deficiency results in modulation of serum lipids, glutathione, and NO synthase isozyme activationin cardiovascular tissues: relevance to de novo synthesis of ceramide, serum $\mathrm{Mg}$ and atherogenesis. Int J Clin Exp Med 4: 103-118.

58. Altura BM, Shah NC, Shah GJ, Zhang A, Li W, et al. (2012) Short-term magnesium deficiency upregulates ceramide synthase in cardiovascular tissues and cells: crosstalk among cytokines, $\mathrm{Mg} 2+, \mathrm{NF}-\mathrm{kB}$ and de novo ceramide. Am J Physiol Heart Circ Physiol 302: H319-H332.

59. Altura BM, Shah NC, Shah GJ, Li W, Zhang A, et al. (2013) Magnesium deficiency upregulates sphingomyelinases in cardiovascular tissues and cells: cross-talk among proto-oncogenes, Mg2+, NF-kB, and ceramide and their potential relationships to resistant hypertension, atherogenesis and cardiac failure. Int J Clin Exp Med 6: 861879

60. Shah NC, Shah GJ, Li Z, Jiang X-C, Li W, Zhang A, et al. (2014) Short-term magnesium deficiency downregulates telomerase, upregulates neutral sphingomyelinase and induces oxidative DNA damage in cardiovascular tissues: relevance to atherogenesis, cardiovascular diseases and aging. Int J Clin Exp Med 7: 497-514.

61. Altura BM, Shah NC, Shah GJ, Altura BT (2016) Genotoxic effects of magnesium deficiency in the cardiovascular system and their relationships to cardiovascular diseases and atherogenesis. J Cardiovasc Dis Diagnosis S1: 009.

62. Zheng T, Wang J, Altura BT, Altura BM (2000) Sphigomyelinase and ceramide analog induce contraction and rises in $[\mathrm{Ca} 2+]$ in canine cerebral vascular muscle. Am J Physiol Heart Circ Physiol 278: H1421-H1428.

63. Altura BM, Gebrewold A, Zheng T, Altura BT (2002) Sphingomyelinase and ceramide induce vasoconstriction and leukocyte-endothelial interactions in cerebral venules in the intact rat brain: insight imto mechanisms and possible relation to brain injury and stroke. Brain Res Bull 58: 539-553.

64. Bischoff A, Czyborra P, Fetscher C, Meyer zu Heringdorf D, Jakobs KH, et al. (2000) Sphingosine-1-phosphate and sphingosylphorylcholine constrict renal and mesenteric microvessels. Br J Pharmacol 130: 1871-1877.

65. Augé N, Nègre-Salvayre A, Salvayre R, Levade T (2000) Sphingomyelin metabolites in vascular cell signaling and atherogenesis. Prog Lipid Res 39: 207-229. [Crossref]

66. Fruhwirth GO, Loidl A, Hermetter A (2007) Oxidized phospholipids: from molecular properties to disease. Biochim Biophys Acta 1772: 718-736. [Crossref]

67. Prescott SM, Zimmerman GA, Stafforini DM, McIntyre TM (2000) Platelet-activating factor and related lipid mediators. Annu Rev Biochem 69: 419-445. [Crossref]

68. Montrucchio G, Alloatti G, Camussi G (2000) Role of platelet-activating factor in cardiovascular pathophysiology. Physiol Rev 80: 1669-1699. [Crossref]

69. Altura BM, Li W, Zhang A, Shah NC, Shah GJ, et al. (2016) The expression of plateletactivating factor is induced by low extracellular $\mathrm{Mg} 2+$ in aortic, cerebral and neonatal coronary vascular smooth muscle; cross-talk with ceramide production, NF-kB and prot-oncogenes: possible links to atherogenesis and sudden cardiac death in childre and infants, and aging: Hypothesis, review and viewpoint. Int J Cardiol Res 3: 47-67.

Copyright: (C2016 Altura BM. This is an open-access article distributed under the terms of the Creative Commons Attribution License, which permits unrestricted use, distribution, and reproduction in any medium, provided the original author and source are credited. 